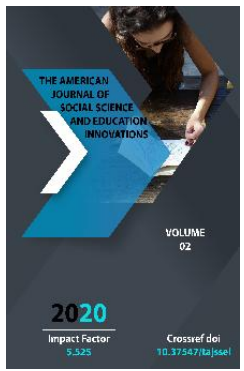

\title{
Shaping Pupils' Spirituality Through Creating Texts (Based On Mother Tongue Textbook Materials For 8th Grade)
}

\author{
Sanoyeva Mutabar
}

Independent Researcher Of Navoi State Pedagogical Institute, Uzbekistan

Journal Website:

http://usajournalshub.c

om/index,php/tajssei

Copyright: Original

content from this work

may be used under the

terms of the creative

commons attributes

4.0 licence.

\section{ABSTRACT}

The main purpose of creating texts in mother tongue lessons is to inculcate in the minds of pupils the ideas of national independence - to teach the next generation to be spiritually mature, patriotic, to look at their nation and national traditions, ancient values. It is the upbringing of a perfect and virtuous person who is able to preserve his ideals, who has mastered the science of maturity and eloquence.

\section{KEYWORDS}

Mother tongue education, text, classical text, dictionary, creative thinking, observation, comparison, conversation, speaking skills.

\section{INTRODUCTION}

Pupil work - the organization of educational activities with a specific purpose, the effective management of the educational process, its direction - the scientific potential of the mother tongue teacher, pedagogical skills, age and The ability to take into account his interests is determined by his ability to have a positive impact on his consciousness and spiritual outlook. To inculcate in the minds of pupils the ideas of national independence - the next generation is spiritually mature, patriotic, able to preserve their nation and national traditions, ancient values, mastered the science of maturity and eloquence. and is the upbringing of a virtuous person.

\section{MATERIALS AND METHODS}

The formation of independent and creative thinking skills in the minds of pupils, the use of a step-by-step system of direct text creation for the development of the idea of national independence gives good results [1]. Linguists 
have also expressed a number of views on this issue $[3,4,5]$.

This system, which is extremely useful not only for mother tongue education, but also for learning a second language, is aimed at revealing dozens of lexical phraseological groups and their possibilities in the text, in the process of creating an independent text based on the principles of continuity and continuity. the pupil's vocabulary, the ability to form combinations from words, the ability to compose sentences, the level of text creation to determine and evaluate the four separate, as well as interdependent, complementary and summative stages consists of.

The first stage in the step-by-step system of text creation is "Word choice", in which the pupil's vocabulary (the amount of words and concepts present in the child's mind), the ability to create new words corresponds to the studied topic. and the ability to search for specific words and select the most appropriate ones is identified and evaluated.

In the second stage, the pupil creates an indicator resource for the correct combination of existing words in the dictionary, new word combinations, the direction of the sentence to be formed. acquires skills to do.

The third stage of this process is the basis for speech. In the next work, the pupil will determine what to base, what to explain, what concepts to explain, the scope, scope, boundaries of thought. The pupil predetermines in what area, in what direction, in what content the sentence will be formed. Abstraction is replaced by clarity, purposefulness. The way of thinking, the state of thinking, the direction is visible.
The third stage - the realization of the product of thinking, expressed in a certain pattern - is devoted to the ability to compose a sentence. The main focus is on the formation and development of pupils' skills of methodologically and logically correct, perfect speech. Prevention of inaccuracies, repetitions, spelling, punctuation and methodological errors, the ability to form flawless speech. The pupil has the opportunity to consciously find and correct mistakes. The most interesting and positive thing is that the pupil creates the necessary sequence of sentences for the text to be composed. The selected word, the phrase formed and the speech that is born with their help, is a product of independent and creative thinking a practical application of the system of knowledge, skills and abilities acquired by the pupil.

The fourth and final stage in this system is the creation of the text, that is, the discovery of a methodologically and logically perfect text, using the knowledge, skills and abilities acquired in the process of language teaching to express a consistent and continuous opinion.

\section{RESULTS AND DISCUSSIONS}

Improving pupils' speaking skills means imparting specific skills to them. Pupils will learn the following skills from developing connected speech as an independent exercise:

1. Ability to understand a topic, define boundaries, and cover it relatively fully. For example, in the 8th grade mother tongue textbook, the topic is "Etiquette to treat with respect and care" [2], pupils prepare a short radio talk on the text and express their creative ideas. In order for 
them to better understand the topic, Abdullah Avloni's wisdom about manners mentioned in the previous assignment will be retold, and radio speeches will be practiced through independent storytelling on the given topic, with questions and assignments.

2. The ability to subordinate the text to the main idea. The main activity of the pupils is to express a certain idea (understanding the wonderful image of nature, pride in their happy life, love for work and hardworking people).

3. Gather material related to the story, the topic of the text, and the need to cover it. This also applies to the statement, where the sample text is analyzed, the content is worked on, and the main content is highlighted.

4. Ability to organize the material, place it in the appropriate sequence, create a text plan and write on the basis of this plan.

Ability to express ideas correctly in accordance with the norms of literary language. The text and the statement are prepared linguistically before it is formed orally.

$>$ Ability to compose a text orally or in writing, to write a text, that is, to complete all the preparatory work.

$>$ Ability to improve written text. This skill is nurtured through a critical approach to one's own creativity. Pupils will be taught to identify mistakes in the selection and placement of material, word selection, word combinations, and sentence construction.

In preparing the pupil for the next text, the teacher needs to clearly consider the pedagogical purpose of the exercise, what to teach the pupils, how to enrich their thinking and speech, and the role of the text in the sequence of exercises. Therefore, it is recommended that pupils develop a one-year plan for related speech development exercises. The plan should take into account all types of age-appropriate text and narration.

According to the methodological tradition, textual exercises are divided into description, narration and discussion. In Grade 8, these are mainly expressed in the form of a story with elements of imagery or discussion.

The material used for all three genres has its own characteristics, both in character and construction, and in the choice of language tools. When preparing a text or statement, the teacher (or reader) takes into account the genre characteristics of the text.

The story is a suitable genre for 8th graders because it is lively and moving. There are many such texts in the textbook.

The image has no subject, no participants; it describes nature, certain objects and events. Pupils read many of the descriptive texts in the Mother Tongue book, retell them, and describe the text, some objects, or events. For example, "My mother is my love", "Autumn in Uzbekistan". The peculiarity of the image is that it has a lot of quality, comparison. Illustration is a more difficult genre for pupils than storytelling, so pupils write story-type texts and essays with more visual elements.

Discussion is a more difficult form of related text, so it is recommended to write a discussion text in the 8th grade curriculum; pupils use more discussion elements in the essay. For example, it is recommended to write an essay on "New Age Generations", "I am a fan of Abdulla Aripov's poems." In such 
an essay, there is, of course, an element of discussion.

When planning a connected speech, the teacher involves practice in a variety of genres and teaches pupils the elements of storytelling, imagery, and discussion. It focuses on composing more story-type text. Depending on the level of pupils' mastery of connected speech, elements of description and discussion are included in the text.

\section{CONCLUSION}

Through the creation of texts, pupils grow up with spiritual qualities such as a sense of the beautiful image of nature, pride in their happy lives, and a love of work and hardworking people.

\section{REFERENCES}

1. Ziyodova T. Education through text creation. Materials of the 7 th meeting of the regular conference "Uzbek language". Tashkent. 2003, p.43.

2. Nigora M. The historical development of the language-the basis of human history // International Journal on Integrated Education. - 2019. - T. 2. - №. 4. - S. 119-121.

3. Jumayevna Y. N. Linguo culture logical features of metaphors in children's literature (On the example of khudayberdi tokhtabayev's creative work) // ACADEMICIA: An International Multidisciplinary Research Journal. - 2019. - T. 9. - №. 4. - p. 139-145.

4. Norboyevna Y. R. Structural-semantic, national-cultural features of words in Uzbek language // Asian Journal of Multidimensional Research (AJMR). 2020. - T. 9. - №. 5. - p. 409-414. 